\title{
Ionic Channels as Potential Therapeutic Targets for Erectile Dysfunction: A Review
}

\author{
Anderson Fellyp Avelino Diniz ${ }^{1+}$, Rafael Carlos Ferreira ${ }^{1+}$, lara Leão Luna de Souza ${ }^{2}$ \\ and Bagnólia Araújo da Silva ${ }^{1 *}$
}

1 Programa de Pós-Graduação em Produtos Naturais e Sintéticos Bioativos, Universidade Federal da Paraíba, João Pessoa, Brazil, ${ }^{2}$ Departamento de Ciências Biológicas e da Saúde, Universidade Estadual de Roraima, Boa Vista, Brazil

OPEN ACCESS

Edited by:

Domenico Tricarico,

University of Bari Aldo Moro, Italy

Reviewed by:

Ulf Simonsen,

Aarhus University, Denmark

Heike Wulff,

University of California,

Davis, United States

${ }^{*}$ Correspondence:

Bagnólia Araújo da Silva bagnolia@ltf.ufpb.br

${ }^{\dagger}$ These authors have contributed equally to this work

Specialty section: This article was submitted to Pharmacology of lon Channels and Channelopathies,

a section of the journal

Frontiers in Pharmacology

Received: 06 May 2020 Accepted: 10 July 2020 Published: 24 July 2020

Citation:

Diniz AFA, Ferreira RC, de Souza ILL and da Silva BA (2020) lonic Channels

as Potential Therapeutic Targets for Erectile Dysfunction: A Review.

Front. Pharmacol. 11:1120. doi: 10.3389/fphar.2020.01120
Erectile dysfunction (ED) is a prevalent condition, especially in men over 40 years old, characterized by the inability to obtain and/or maintain penile erection sufficient for satisfactory sexual intercourse. Several psychological and/or organic factors are involved in the etiopathogenesis of ED. In this context, we gathered evidence of the involvement of Largeconductance, $\mathrm{Ca}^{2+}$-activated $\mathrm{K}^{+}$channels $\left(\mathrm{BK}_{\mathrm{Ca}}\right)$, Small-conductance, $\mathrm{Ca}^{2+}$-activated $\mathrm{K}^{+}$ channels (SK $\mathrm{C}_{\mathrm{Ca}}$ ), KCNQ-encoded voltage-dependent $\mathrm{K}^{+}$channels $\left(\mathrm{K}_{\mathrm{V}} 7\right)$ ), Transient Receptor Potential channels (TRP), and Calcium-activated Chloride channels (CaCC) dysfunctions on ED. In addition, the use of modulating agents of these channels are involved in relaxation of the cavernous smooth muscle cell and, consequent penile erection, suggesting that these channels are promising therapeutic targets for the treatment of erectile dysfunction.

Keywords: canalopathies, erectile dysfunction, $\mathrm{Ca}^{2+}$-activated $\mathrm{K}^{+}$channels, $\mathrm{KCNQ}$-encoded voltage-dependent $\mathrm{K}^{+}$ channels, transient receptor potential channels, calcium-activated chloride channels

\section{INTRODUCTION}

Erectile dysfunction (ED) is a persistent inability to achieve and/or maintain a penile erection enough for satisfactory sexual intercourse (McCabe et al., 2016). Predominantly a vascular disorder, ED affects both physical and psychological health, having a direct impact on men's life quality and their sexual partners, mainly due to a reduction in self-esteem and impairment of interpersonal

\footnotetext{
Abbreviations: $\mathrm{ED}$, Erectile dysfunction; $\mathrm{BK}_{\mathrm{Ca}}$, Large-conductance, $\mathrm{Ca}^{2+}$-activated $\mathrm{K}^{+}$channels; TRP, Transient Receptor Potential; CaCC, Calcium-activated Chloride channels; $\mathrm{K}_{\mathrm{V}} 7$, KCNQ-encoded voltage-dependent $\mathrm{K}^{+}$channels; $\mathrm{SK}_{\mathrm{Ca}}{ }^{2+}$, Smallconductance, $\mathrm{Ca}^{2+}$-activated $\mathrm{K}^{+}$channels; ROS, Reactive Oxygen Species; eNOS; RhoA, Endothelial nitric oxide synthase; Small G protein GTP-binder; ROCK, Rho-associated protein kinase; MS, Metabolic Syndrome; NO, Nitric Oxide; CNS, Central Nervous System; NA, Norepinephrine; NANC, Non-adrenergic, Non-cholinergic; PGI $_{2}$, Prostacyclin; PGE $1 / 2$, Prostaglandins E type 1 and 2; CaM, Calmodulin; $\mathrm{Ca}_{\mathrm{V}}$, Voltage-dependent $\mathrm{Ca}^{2+}$ channels; AC, Adenylyl cyclase; PKA, cAMP dependent protein kinase; PKG, cGMP-dependent protein kinase; ATP, Adenosine triphosphate; GTP, Guanosine triphosphate; cAMP, Cyclic adenosine monophosphate; cGMP, Cyclic guanosine monophosphate; $\mathrm{IP}_{3}$, Inositol 1,4,5triphosphate; SR, Sarcoplasmic reticulum; SERCA, Sarco/endoplasmic reticulum $\mathrm{Ca}^{2+}$ ATPase; MLCK, Myosin light chain kinase; NCX, $\mathrm{Na}^{+} / \mathrm{Ca}^{2+}$ exchanger; PMCA, Plasma membrane $\mathrm{Ca}^{2+}$-ATPase; SHIM, Male Sexual Health Inventory; IIFE, International Index of Erectile Function; PKC, Protein kinase C; RCK $\mathrm{R}_{1 / 2}$, Regulator of potassium conductance; TRPA, Transient Receptor Potential Ankyrin; TRPC, Transient Receptor Potential Canonical; TRPM, Transient Receptor Potential Melastatin; TRPML, Transient Receptor Potential Mucolipine; TRPP, Transient Receptor Potential Polycystin; TRPV, Transient Receptor Potential Vanilloid; AA, Arachidonic acid; TMEM16, Transmembrane protein with unknown function 16A; DNDS, 4,4-dithitrostylbene-2,2-disulfonic acid; NFA, Niflumic acid; A9C, Anthracene-9-carboxylic acid.
} 
relationships (Boddi et al., 2015; Nguyen et al., 2017; Burnett et al., 2018). It mainly affects men after 40 years of age and it has estimated that over 150 million worldwide have some degree of this dysfunction (Ayta et al., 1999; Grover et al., 2006; Riedner et al., 2011; Tabosa et al., 2017). However, even if the increasing in cases with aging is evident, ED is not an inevitable consequence of aging, which makes it possible to increase the estimate of the average world prevalence (Seftel, 2011; Shamloul and Ghanem, 2013; Yafi et al., 2016; Gabrielson et al., 2019).

Psychological and organic factors such as anxiety, stress, depression, or vascular and hormonal dysfunctions may cause imbalance of the contractile and relaxing mechanisms of the cavernous smooth muscle culminating in the development of ED (Andersson, 2001; Fumaz et al., 2017; Mitidieri et al., 2020).

In recent years, researching involving the flaccidity and penile erection has focused mainly on molecular mechanisms. In this sense, several neurotransmitters, second messengers, reactive oxygen species (ROS), growth factors, hormones, and ion channels have been characterized as important components of the complex erection process, leading to the discovery of new therapeutic targets for the treatment of ED. The search for new therapeutic alternatives for erectile dysfunction is associated with refractoriness to conventional treatments observed in part of the male population. Given this, this review will focus on providing an update on the importance of some ion channels involved in the regulation of intracellular signaling and tone of cavernous smooth muscle and their potential as therapeutic targets to the development of new drugs to treatment of erectile dysfunction.

\section{ETIOLOGICAL FACTORS OF ERECTILE DYSFUNCTION}

Multifactorial nature of ED is evident and, population studies have shown that several conditions involving vascular abnormalities such as hypertension, aging, physical inactivity, dyslipidemia, diabetes, insulin resistance, and obesity are among the major risk factors that favor the development of ED in man and animal models (Musicki et al., 2010; Kaya et al., 2015; Maseroli et al., 2015). In addition, studies have shown that ED is a predictive factor for the development of cardiovascular disease and may be a potent marker for screening for silent coronary disease (Phe and Roupret, 2012; Gandaglia et al., 2016; Capogrosso et al., 2019; Orimoloye et al., 2019).

The causes of ED are directly related to biopsychosocial processes that involve psychological, endocrine, vascular, and neurological coordination (Prieto, 2008), and can be classified etiologically as psychological, organic or mixed, where there is a combination of both factors (Ayta et al., 1999; Riedner et al., 2011; Yafi et al., 2016).

The most common psychogenic factors include performance anxiety, psychiatric disorders such as anxiety, stress and depression, and relationship conflicts that culminate in reduced sexual libido or fear of failure during intercourse. Organic factors include neurological, endocrine and vascular causes (Fauci et al., 2012; Swerdloff and Wang, 2012; Mccabe and Althof, 2014). Neurological or neurogenic ED have been represented, mainly, by signaling deficiency through penile innervations (Brackett et al., 2010). Neurological causes have been responsible for approximately 10 to $19 \%$ of ED cases and are among those causes, such as Parkinson's disease, dementia, demyelinating disease and spinal cord injury at levels affecting erection and/or ejaculation (Keller et al., 2012; Ludwig and Phillips, 2014; Antuña et al., 2015). Reduced testosterone levels, hormone responsible for increasing endothelial nitric oxide synthase (eNOS) expression, and reduced protein expression of Small G protein GTP-binding/Rho-associated protein kinase (RhoA/ROCK) pathway characterize endocrine ED (Lugg et al., 1996; Mills et al., 2001; Hu et al., 2009; Sopko et al., 2014). In addition, the main endocrine causes are diabetes mellitus, metabolic syndrome (MS) and changes in sex hormones (Özdemirci et al., 2001; Swerdloff and Wang, 2012; Ludwig and Phillips, 2014; Papagiannopoulos et al., 2015). Arterial traumatic disease, atherosclerosis and systemic arterial hypertension represent the main causes of vascular etiology (Perticone et al., 2005; Fauci et al., 2012), and are directly related to endothelial dysfunction, which may result from imbalance of NO, increased sympathetic activity and structural changes that reduce the relaxing capacity of the corpus cavernosum of the penis (Corona et al., 2006; Jackson, 2007; Swerdloff and Wang, 2012).

Moreover, aging is the major risk factor for ED and both the prevalence and severity of the disease increase with aging, so it is usually caused by the presence of neural and endothelial dysfunction (El-Sacca, 2007; Lewis et al., 2012).

\section{PHYSIOLOGICAL MECHANISMS OF FLACCIDITY AND PENILE ERECTION}

Penis is the male genital and copulatory organ responsible for the elimination of urine and sexual intercourse (Sachs and Meisel, 1988; Katz, 2002). It can be divided into three parts: base, body and glans. Penis base is formed by three cylindrical structures corresponding to two corpus cavernosum and a corpus spongiosum (Eardley et al., 2013).

Corpus cavernosum comprise two parallel smooth muscle cylindrical structures surrounded by a compact fibrous tissue structure, known as the albuginia tunic, which gives the penis rigidity, strength and flexibility (Awad et al., 2011; Doyle, 2011; Avery and Scheinfeld, 2015).

Smooth muscle of the corpus cavernosum is important for erection and maintenance of penile flaccidity. Most of the time, smooth muscle cells remain in their contracted state, which limits the filling of vessels that nourish the corpus cavernosum with blood and, consequently, favor the maintenance of flaccidity (Thomas and Bohnen, 2005; Andersson, 2011). On the other hand, due to neurovascular modulation mediated by psychological and hormonal factors, cavernous smooth muscle cells, in a coordinated manner, may be in their relaxed state, from a complex interaction between the central nervous system (CNS) and local stimuli. As a result, the filling of the corpus cavernosum with increasing intracavernous pressure promote penile erection. Thus, muscle cells of the corpus cavernosum operate together in 
synchronicity, as they not only contract spontaneously in a coordinated manner, but also relax synchronously (Brownstein et al., 2017).

Penile flaccidity process primarily have been stimulated by the sympathetic nervous system, where the release of norepinephrine (NA) by adrenergic neurons stimulates its $\alpha_{1}$ and $\alpha_{2}$ receptors in the smooth muscle of the penile vessels and corpus cavernosum, inducing its contraction and reduction of the blood flow (Goldstein, 2000; Gur et al., 2012; Traish et al., 2015).

Relaxation of the corpus cavernosum causes penile erection in response to cholinergic neurotransmission, with nitric oxide (NO) being the most important neurotransmitter. In addition, nonadrenergic non-cholinergic neurotransmission (NANC) transmitters are also found adrenergic nerves (Andersson, 2011; Hannigan, 2016). Further, other mediators are also responsible for modulating cavernous smooth muscle relaxation, such as prostacyclin $\left(\mathrm{PGI}_{2}\right)$ and type 1 and 2 prostaglandins $\left(\mathrm{PGE}_{1}\right.$ and $\mathrm{PGE}_{2}$ ). These prostanoids act on the $\mathrm{G}_{\mathrm{s}}$ protein-coupled IP, $\mathrm{EP}_{2}$ and $\mathrm{EP}_{4}$ receptors, culminating in activation of ${ }_{c} \mathrm{GMP}$ and ${ }_{c} \mathrm{AMP}-$ dependent protein kinases (PKG and PKA, respectively) which, when activated, phosphorylate various targets such as potassium channels, activating them, and voltage-dependent calcium channels, inhibiting them (Figure 1) (Porst, 1996; Angulo et al., 2002; Andersson, 2011).

\section{DIAGNOSIS OF ERECTILE DYSFUNCTION}

Diagnosis of ED is complex because it results from personal, interpersonal and social implications related to disease, involving the identification of the main signs and symptoms presented by the patient and determination of the stage of disease and use of medicines, with the aim of identifying its primary etiology, reduce associated risk factors, and prevent the harmful effects of diseases correlated with dysfunction (Corona et al., 2006; Glina et al., 2014).

Given this limitation, questionnaires that help determine the real development and severity of ED were standardized and validated. Among them, the most commonly used in clinical practice are the Male Sexual Health Inventory (SHIM), which presents five specific questions about ED and the International Index of Erectile Function (IIFE), which has 15 questions related to all phases of male sexual response (Rosen et al., 2002; Ghanem et al., 2012; Rosen and Spiegelman, 2014).

In addition to a complete survey of the patient's sexual, surgical, psychosocial history, and medication use, the diagnosis of ED requires adequate physical examination, as well as an assessment of blood pressure and weight, given the association of the disease with hypertension and obesity. Another crucial point for the diagnosis of this dysfunction is

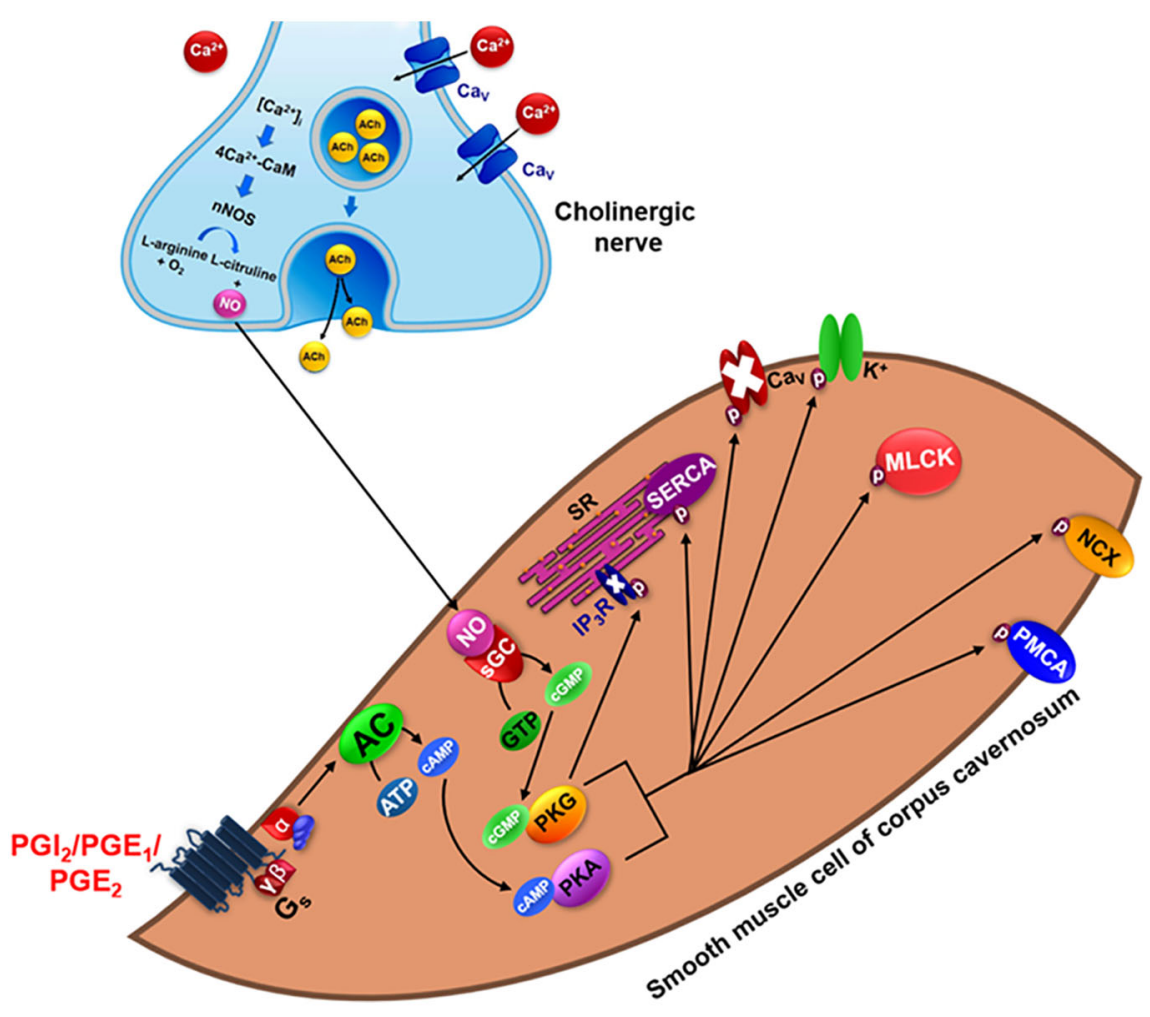

FIGURE 1 | Physiological mechanism of relaxation in the cavernous smooth muscle. CaM, calmodulin; nNOS, neuronal nitric oxide synthase; NO, nitric oxide; Cav, voltage-dependent $\mathrm{Ca}^{2}{ }^{+}$channels; $\mathrm{PGI}_{2}$, prostacyclin; $\mathrm{PGE}_{1 / 2}$, prostaglandin E type 1 and 2; AC, adenylyl cyclase; ATP, adenosine triphosphate; cAMP, cyclic adenosine monophosphate; PKA, cAMP dependent protein kinase; sGC, soluble guanylyl cyclase; GTP, guanosine triphosphate; cGMP, cyclic guanosine monophosphate; PKG, cGMP-dependent protein kinase; GMP, guanosine monophosphate; $\mathrm{IP}_{3}$ :R Inositol 1,4,5-triphosphate receptor; SR, sarcoplasmic reticulum; SERCA, Sarco/endoplasmic reticulum $\mathrm{Ca}^{2+}$ ATPase; MLCK, myosin light chain kinase; NCX, $\mathrm{Na}^{+} / \mathrm{Ca}^{2+}$ exchanger; PMCA, Plasma membrane Ca ${ }^{2+}$-ATPase. 
the evaluation and determination of testosterone levels, since low concentrations of this hormone have been related and contributed to the development of ED (Cordero et al., 2010; El Taieb et al., 2019; Irwin, 2019).

Local penile evaluation is another important alternative because it provides information on the presence of penile deformities, elasticity, urethral meatus, testicular consistency, and fibrosis plaques, which are related to penile erection impairment (Shamloul and Ghanem, 2013). Based on the aforementioned assessments, it is possible to differentiate the etiology of disease from psychogenic or organic, and more precisely the target the treatment of ED.

\section{TREATMENT OF ERECTILE DYSFUNCTION}

Treatment of ED is performed according to the clinical evaluation of the patient, and it can be divided into non-pharmacological and pharmacological. The non-pharmacological therapy is based on lifestyle modifications, including control of glycemic levels and lipid profile (cholesterol and triglycerides), reduction in addition to stopping smoking and alcohol use, as well as the practice of physical activity (Kupelian et al., 2007; Maiorino et al., 2015). There are currently surgical interventions, devices penile devices, and psychotherapy, used as alternatives for non-pharmacological treatment. In addition, there is hormone replacement and the use of drugs that constitute the pharmacological treatment of this disease (Eardley et al., 2010; Hatzimouratidis et al., 2010).

Oral therapy is the first line treatment for erectile dysfunction and involves the use of PDE5 inhibitors such as sildenafil, which is the prototype of the group, tadalafil, vardenafil and iodenafil. Mechanistically, these drugs facilitate erection by inhibiting the enzyme PDE5, which is responsible for cGMP degradation in smooth cavernous muscle. This inhibition results in prolonged cGMP activity, which decreases cytosolic calcium concentrations, maintaining corpus cavernosum relaxation and, thus, promotes penile erection with a success rate of over 65\% (Konstantinos and Petros, 2009; Andersson, 2011; Selph and Carson, 2011). However, previous sexual stimulation is essential to increase intracellular NO levels and, consequently, to cGMP generation (Yafi et al., 2016).

Side effects related to PDE5 inhibitor therapy include, mainly, headache, nasal congestion, facial flushing and dyspepsia. The onset of action of the drug is around 30-60 min, lasting approximately $4-8 \mathrm{~h}$. The main contraindications are nitratecontaining compounds, cardiovascular events, non-arteritic ischemic optic neuropathy and $\alpha$-blockers (Brant et al., 2007; Zelefsky et al., 2014).

Currently, intracavernous and intraurethral therapies include, mainly alprostadil, with a high therapeutic success rate (90\%) (Hatzimouratidis and Hatzichristou, 2005; Perimenis et al., 2006), representing the second line of treatment for ED. Its advantages are the rapid onset time, around $10 \mathrm{~min}$, and the quality of penile erections, even in the absence of sexual stimulation (Shamloul and Ghanem, 2013). Additionally, alprostadil is synthetic prostaglandin $\mathrm{E}_{1}$, which by binding to $\mathrm{EP}_{2 / 4}$ receptors activates the adenylyl cyclase
(AC) signaling pathway, culminating in the increase of cAMP cytoplasmic concentration, which ultimately results in the corpus cavernosum relaxation and, consequently, the penile erection. It has used in intracavernous injection therapy and as a suppository for intrauretal use (Moreland et al., 2003).

Despite the great therapeutic success of the drugs, around 30\%$40 \%$ of men with ED do not respond to this first line of treatment. Additionally, the use of injectable medications brings priapism as the main risk, which consists of a painful and prolonged penile erection (greater than two hours), regardless of sexual desire and resulting from insufficient penile blood drainage. In this context, refractoriness to conventional treatments contributes to the search for new therapeutic alternatives for ED (Alves et al., 2012; Codevilla et al., 2013; Munk et al., 2019).

\section{ION CHANNELS AND ERECTILE DYSFUNCTION}

\section{Large-Conductance, $\mathrm{Ca}^{2+}$-Activated $\mathrm{K}^{+}$ Channels (BK $\mathrm{Ca}_{\mathrm{Ca}}$}

The $\mathrm{BK}_{\mathrm{Ca}}$ channels are highly conductive (150-250 pS) channels, selective for $\mathrm{K}^{+}(\mathrm{Wu}, 2003)$ with ubiquitous expression on the plasma membranes of all eukaryotic cells. They are activated in a negative feedback mechanism to control plasmatic membrane excitability in response to membrane voltage and increased cytoplasmic $\mathrm{Ca}^{2+}$ concentration. Its dysfunction is implicated in several diseases, including erectile dysfunction (Kshatri et al., 2017; Gururaja Rao et al., 2019).

These channels are constituted by a tetramer of $\alpha$ subunits, encoded by the Slo gene, which form the channel pore, and auxiliary subunits $\beta_{1}-\beta_{4}$ and $\gamma_{1}-\gamma_{4}$ that modulate the physiological activity of these channels (Figure 2A) (Contreras et al., 2013; Kshatri et al., 2017). The association with the $\beta_{1}$ subunit, for example, decreases voltage dependence and increases apparent sensitivity to $\mathrm{Ca}^{2+}$ (McManus et al., 1995; Wallner et al., 1995; Lorca et al., 2014a; Lorca et al., 2014b; Balderas et al., 2015).

The $\alpha$ subunits are formed by seven transmembrane segments (S0 - S6) with N-terminal domain located in the extracellular region and $\mathrm{C}$-terminal domain, which has the $\mathrm{Ca}^{2+}$ sensor domain, located intracellularly. Voltage sensor comprises segments S0 to S4 and the pore-forming domain includes segments S5 and S6 (Figure 2B) (Schubert and Nelso, 2001).

Modulation of $\mathrm{BK}_{\mathrm{Ca}}$ channels involves several mechanisms. Phosphorylation of channel-forming protein by PKA or PKG may activate or inhibit them, depending on type of smooth muscle evaluated. In pulmonary artery smooth muscle, protein kinase $\mathrm{C}(\mathrm{PKC})$ inhibits $\mathrm{BK}_{\mathrm{Ca}}$ channels, causing pulmonary vasoconstriction (Barman et al., 2004; Werner et al., 2005).

Additionally, Kun and colleagues (Kun et al., 2009) observed that NS11021 (1-(3,5-bis-trifluoromethyl-phenyl)-3-[4-bromo-2(1h-tetrazol-5-yl)-phenyl]-thiourea), a BKCa opener, increases the currents sensitive to the selective BKCa channel blocker, iberiotoxin (IbTX) in rat isolated corpus cavernosum smooth muscle cells, and reduced $\left[\mathrm{Ca}^{2+}\right] \mathrm{i}$, and tension in penile arteries, leading to relaxation 


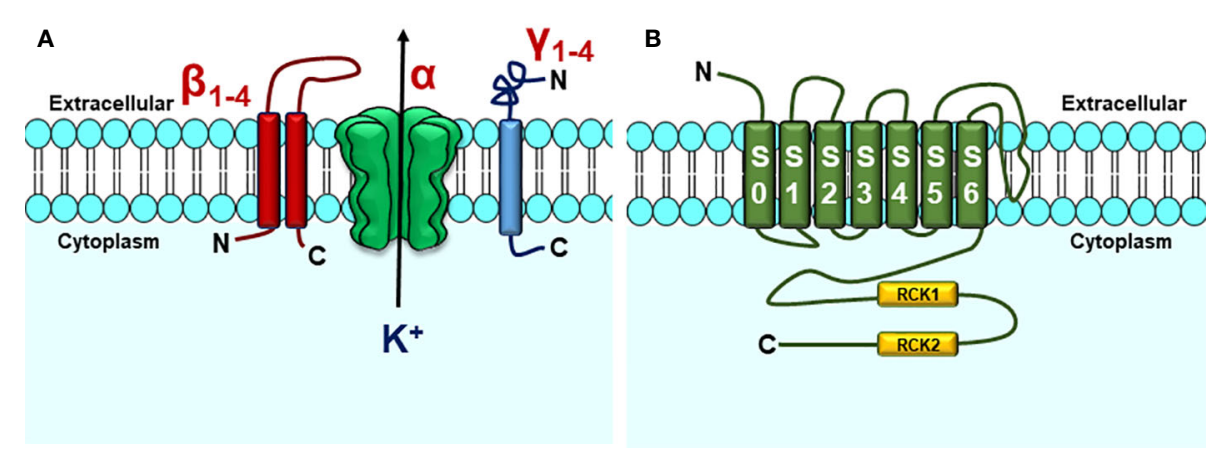

FIGURE 2 | Structure of $\mathrm{BK}_{\mathrm{Ca}}$ channels. (A) BK $\mathrm{CK}_{\mathrm{C}}$ channels are formed by three protein subunits $(\alpha, \beta$, and $\gamma)$. The $\alpha$ subunit forms the channel pore, permeable to $\mathrm{K}^{+}$; (B) Seven transmembrane segments form the $\alpha$ subunit. In C-terminal domain, two $\mathrm{Ca}^{2+}$-sensitive sites are found, known as regulator of potassium conductance (RCK) 1 and RCK2. Adapted from (Schubert and Nelso, 2001).

of the intracavernous arteries, being potential targets for the treatment of ED (Kun et al., 2009). The results obtained by Sung and colleagues showed that another activator of these channels, LDD175, improved erectile function in a diabetic rat model. Furthermore, they showed that LDD175 treatment combined with sildenafil had an additive effect on improving the erectile function of diabetic rats (Nilius and Owsianik, 2011; Sung et al., 2017). These findings suggest that $\mathrm{BK}_{\mathrm{Ca}}$ channels are possible targets for the treatment of ED.

\section{Small-Conductance, $\mathrm{Ca}^{2+}$-Activated $\mathrm{K}^{+}$ Channels (SK $\left.\mathrm{Ca}_{\mathrm{C}}\right)$}

SK are small condutance (10-20 pS) (Kushwah et al., 2018), voltageindependent and cytosolic $\mathrm{Ca}^{2+}$ sensivite channels (Cui et al., 2014). The pore of these channels is selective to $\mathrm{K}^{+}$and formed to four subunits (Figure 3A) each with six transmembrane $\alpha$ helice domains (S1-S6) and intracellular $\mathrm{N}$ - and C-terminus. A loop between the S5 and S6 segments forms the $\mathrm{K}^{+}$selectivity filter (Faber, 2009; Nam et al., 2017) (Figure 3B).
Constitutively linked to the channel, in Calmodulin Binding Domain (CaMBD), the calmodulin protein (CaM) mediates the gating of the pore of SK channel (Zhang et al., 2012) after its interaction with $\mathrm{Ca}^{2+}$ ions. The rise of cytosolic concentration of $\mathrm{Ca}^{2+}$ to about 300-500 nM induces conformation rearrangements in calmodulin and canal subunits, following $\mathrm{K}^{+}$ efflux and membrane hyperpolarization (Keen et al., 1999).

These channels are highly conserved in mammals (Adelman et al., 2012), having identified three clones denominated as SK1 $\left(\mathrm{K}_{\mathrm{Ca}} 2.1\right)$, SK2 $\left(\mathrm{K}_{\mathrm{Ca}} 2.2\right)$, and SK3 $\left(\mathrm{K}_{\mathrm{Ca}} 2.3\right)$ encoded by the genes KCNN1, KCNN2, and KCNN3, respectively (Kouba et al., 2020).

SK channels are distributed in various tissues. In particular, a significant abundance of the SK3 channel had been detected in human corpus cavernosum, after analysis of mRNA distribution by PCR-RT. In addition, high SK3-type immunoreactivity have been observed in cavernous and vascular smooth muscle, and in human vascular endothelium (Chen et al., 2004). ComermaSteffensen and colleagues (2017) observed that SK3 channels were, among the subtypes of SK channels, the most expressed in

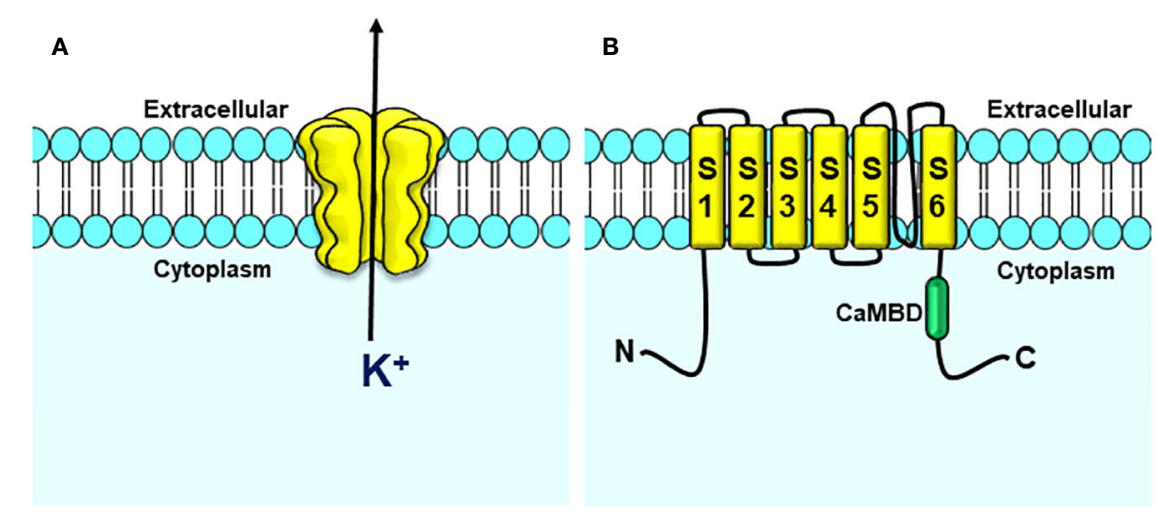

FIGURE 3 | Structure of SK channels. (A) Four subunits form the channel pore permeable to $\mathrm{K}^{+}$ion. (B) Each channel subunit is formed for six transmembrane segments (S1-S6). In C-terminus, is this located the Calmodulin Binding Domain (CaMBD). 
the corpus cavernosum of mice (Comerma-Steffensen S. et al., 2017).

The expression of these channels in vascular endothelial cells is involved in NO production. Sheng and Braun (Sheng and Braun, 2007) observed that blocking SK channels by apamine, inhibited NO synthesis in human umbilical vein endothelial cells (HUVERs) (Sheng and Braun, 2007). As reviewed by Félétou (Félétou, 2009), events such as the activation of $G$ protein-coupled receptors or shear stress in endothelial cells, induce an increase in the cytosolic concentration of $\mathrm{Ca}^{2+}$, activating $\mathrm{SK}_{\mathrm{Ca}}$ following hyperpolarization of the endothelial cells. As a result, the additional influx of $\mathrm{Ca}^{2+}$, favored by increasing electrochemical driving force, and the consequent activation of $\mathrm{NO}$ synthase, induces the release of NO by endothelial cells and relaxation of the vascular smooth muscle cells (Félétou, 2009).

In diabetic Sprague-Dawley rats, Zhu and colleagues (Zhu et al., 2010) observed reduction in the frequency of penile erections, after administration of apomorphine, and mRNA and SK3 protein levels reduction in the cavernous tissue of these animals, compared to group of non-diabetic rats (Zhu et al., 2010).

The use of a non-selective activator of $\mathrm{K}_{\mathrm{Ca}} 2$ and $\mathrm{K}_{\mathrm{Ca}} 3.1$ channels (NS309), induced relaxation of the corpus cavernosum of mice in concentration dependent manner. It has also been observed, in transgenic animals with overexpression of SK3 channels, a significant reduction in blood mean pressure, when compared to downregulation and wild SK3 animals. In addition, stimulation of the cavernous nerve improved the erectile function of animals with SK3 overexpression, while this effect was reduced in SK3 downregulation animals (Comerma-Steffensen S. et al., 2017). Furthermore, the relaxation of strips of the corpus cavernosum of mice, induced by NS309, was significantly reduced by the removal of endothelial cells, the use of NO synthase blockers and the use of apamine, which reflects the influence of these channels on endothelial and erectile functions (Comerma-Steffensen S. G. et al., 2017).

Thus, evidence of the participation of SK channels in penile erection, suggests that the use of activators of these channels may be of therapeutic interest for the treatment of ED.

\section{KCNQ-Encoded Voltage-Dependent $\mathrm{K}^{+}$ Channels (Kv)}

The voltage-dependent potassium channels encoded by KCNQ $\left(\mathrm{K}_{\mathrm{v}} 7\right)$ include a family of five members $\left(\mathrm{K}_{\mathrm{v}} 7.1\right.$ to 7.5 or KCNQ15) form subunits of the low-threshold voltage-gated $\mathrm{K}^{+}$channel originally termed the 'M-channel', being formed by six transmembrane domains, a single $\mathrm{P}$ loop found between S5 and S6, which forms the pore selectivity filter, a fourth positively charged transmembrane domain (S4) that acts as a voltage sensor and a long carboxy terminal tail intracellular (Jentsch, 2000; Brown et al., 2009; Jepps et al., 2013; Lee et al., 2018) (Figure 4).

These channels are predominantly expressed in the heart, central nervous system, auditory system and smooth muscle of the vessels, functioning as essential regulators of membrane excitability, playing important physiological roles such as potassium homeostasis, cardiac action potential and neuronal excitability, as well as dysfunctions of the $\mathrm{K}_{\mathrm{v}} 7$ channels are associated with human diseases, including cardiac arrhythmias, epilepsy, deafness, hypertension, and erectile dysfunction (Robbins, 2001; Abbott, 2014; Haick and Byron, 2016).

Additionally, it has been reported the importance of $\mathrm{K}_{\mathrm{v}} 7$ channels in the regulation of vascular and non-vascular smooth muscle tone, and that the KCNQ genes $\left(\mathrm{K}_{\mathrm{v}} 7.1,7.4\right.$ and 7.5$)$ are the most expressed subtypes in these muscles, opening a new field of possibilities for pharmacological targeting for the various pathophysiological disorders of the underlying vascular smooth muscle (Greenwood and Ohya, 2009; Soldovieri et al., 2011; Stott et al., 2014).

The pharmacological modulation of these channels in the vessels is responsible for profound changes in the smooth muscle membrane potential and, consequently, in the vasoconstrictor or vasodilator responses of the vascular tone (Jepps et al., 2013). In addition, $\mathrm{K}_{\mathrm{v}} 7$ are also functional endpoints of $\mathrm{G}_{\mathrm{s}}$-linked receptor agonists (Chadha et al., 2012; Khanamiri et al., 2013; Chadha et al., 2014; Stott et al., 2015).

Several studies have been shown that non-selective blocking of $\mathrm{K}_{\mathrm{v}}$ 7.1-7.5 channels by linopirdine and XE991, promote
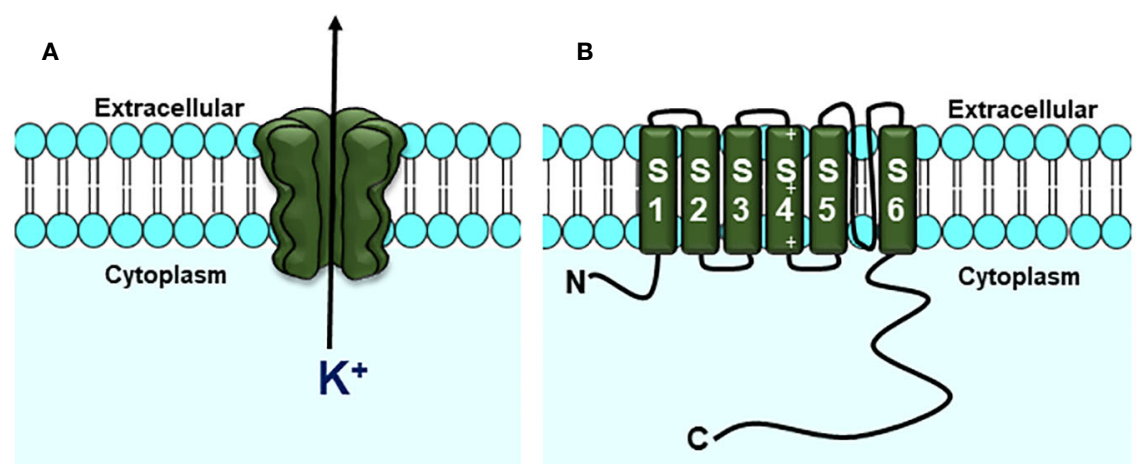

FIGURE 4 | Structure of $K_{V} 7$ channels. (A) Four subunits form the channel pore permeable to $\mathrm{K}^{+}$ion. (B) Each channel subunit is formed for six transmembrane segments (S1-S6). 
membrane depolarization and concomitant vasoconstriction, leading to an increase in calcium influx through voltage-gated calcium channels $\left(\mathrm{Ca}_{\mathrm{V}}\right)$ and consequently inhibit vascular relaxing responses in humans and rodents (Yeung et al., 2007; Yeung et al., 2008; Mackie et al., 2008; Zhong et al., 2010; Jepps et al., 2011; Stott et al., 2015; Lee et al., 2020), which may produce spontaneous contractions in some vessels (Yeung et al., 2007; Mackie et al., 2008; Lee et al., 2020). It has been shown in penile physiology that blocking these channels also impairs arterial relaxation produced by the atrial natriuretic peptide and sodium nitroprusside (SNP), decreasing the cellular concentration of cGMP, essential for the penile erection process (Stott et al., 2015; Jepps et al., 2016).

However, $\mathrm{K}_{\mathrm{v}} 7$ activators (retigabine, ML213 and S-1), hyperpolarize the membrane potential and cause relaxation of pre-contracted vessels, decreasing the $\mathrm{Ca}^{2+}$ influx by $\mathrm{Ca}_{\mathrm{V}}$, resulting in the relaxation of human and rodent arteries (Yeung et al., 2007; Yeung et al., 2008; Mackie et al., 2008; Joshi et al., 2009; Zhong et al., 2010; Chadha et al., 2012). In addition, genes for KCNQ3-5 had been detected in penile arteries, veins and corpus cavernosum, while KCNQ1 was found only in the corpus cavernosum of rats. The activators $\mathrm{K}_{\mathrm{v}}$ 7.2-7.5, ML213, and BMS204352, relaxed pre-contracted penile arteries and corpus cavernosum, regardless of nitric oxide synthase or hyperpolarization derived from the endothelium. In contrast, the relaxation promoted by sildenafil and sodium nitroprusside had been reduced by blocking these channels with linopirdine in the penile arteries and the corpus cavernosum (JEPPS et al., 2016).

Therefore, suggesting that $\mathrm{K}_{\mathrm{v}} 7$ channels play an important functional role in all smooth muscle systems, specifically in erectile function, confirming the potential of these channels as new therapeutic targets for erectile dysfunction.

\section{Transient Receptor Potential Channels (TRP)}

TRP channels are a superfamily of ion channels, mostly nonselective for mono and divalent cations, expressed in almost all cell types, in both excitable and non-excitable tissues and participating in various physiological functions such as nociception and muscle contraction (Smani et al., 2015; Moran, 2018).

In mammals, the TRP superfamily is divided into six subfamilies based on their homology sequences and named according to first described member of each subfamily: ankyrin (TRPA), canonical (TRPC), melastatin (TRPM), mucolipine (TRPML), polycystin (TRPP), and vanilloid (TRPV) (Caterina, 2014; Samanta et al., 2018).

Structurally, TRP channels may be homo or heterotetramers, with each channel-forming subunit composed by six transmembrane segments (S1-S6), with the channel pore located between segments S5 and S6 and amino and carboxiterminal domains located intracellularly (Figure 5) (Smani et al., 2015; Reggio et al., 2018; Blair et al., 2019).

Activity of these channels can be regulated by a wide variety of stimuli including temperature changes, mechanical forces, lipid mediators such as arachidonic acid (AA) and its metabolites (Del Rocío Cantero et al., 2015) and action of protein kinases such as PKA (Jung et al., 2010).

Recently, studies using negative domain gene transfer to TRP channels have helped to understand the involvement between ED and dysfunctions in TRP channels. TRPC6 ${ }^{\text {DN }}$ gene transfer reduced cytoplasmic $\mathrm{Ca}^{2+}$ concentration in human cavernous smooth muscle and restored erectile function in diabetic rats (Sung et al., 2014). Sung and colleagues (Falzone et al., 2018) showed increased expression of TRPC4 in smooth corpus cavernosum muscle cells of diabetic rats and demonstrated that after TRPC4 ${ }^{\mathrm{DN}}$ gene transfer, erectile function of diabetic animals was restored (Falzone et al., 2018).

Taken together, these results indicate the possible involvement of TRP channels in pathophysiology of ED, making them potential targets for the development of drugs to treat this pathological condition.

\section{$\mathrm{Ca}^{2+}$-Activated $\mathrm{Cl}^{-}$Channels (CaCC)}

$\mathrm{CaCC}$ channels belong to a family of transmembrane proteins known as TMEM16 (transmembrane protein with unknown function 16A) (Falzone et al., 2018) (Figure 6). Activation of these channels requires an increase in cytoplasmic calcium concentration in the range of $100 \mathrm{nM}$ to $1-2 \mu \mathrm{M}$, which may be due to inflow or release from intracellular stocks, allowing $\mathrm{Cl}^{-}$ to flow through the plasma membrane (Hartzell et al., 2005; Whorton, 2014; Kamaleddin, 2018).

In smooth muscle, the activation of these channels and consequent chloride efflux induce cell membrane depolarization and voltage-dependent calcium channel activation, resulting in additional $\mathrm{Ca}^{2+}$ influx and muscle contraction, having, in particular, an important physiological role in contraction of smooth muscles of the corpus cavernosum, a necessary action for penile flaccidity. Thus, inactivation of these channels by pharmacological agents is a therapeutic alternative for the

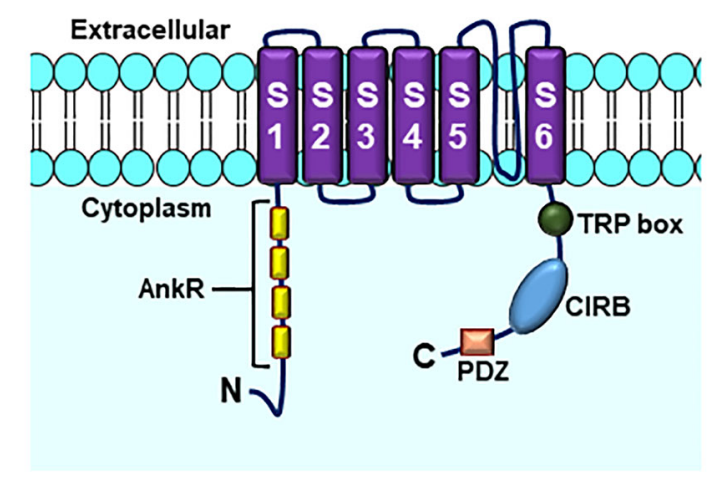

FIGURE 5 | Structure of TRPC channels. AnkR, ankyrin repeats (number differs by subfamily members); TRP box; CIRB, calmodulin- and inositol triphosphate receptor (InsP3R)-binding site; PDZ, amino acid motif binding PDZ domains. Based on (Cao et al., 2018). 


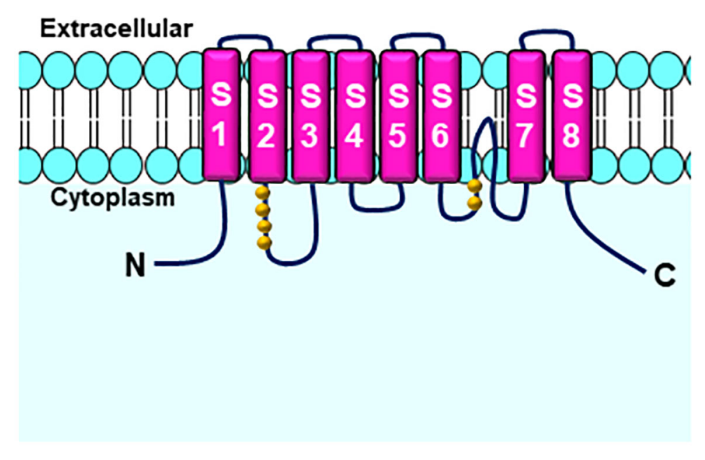

FIGURE 6 | Six transmembrane domains form the Calcium-activated Chloride channels (CaCC)s. Glutamate residues (yellow beads) are potential $\mathrm{Ca}^{2+}$ binding sites. Adapted from (Picollo et al., 2015).

treatment of ED (Chu and Adaikan, 2008; Linton et al., 2012; Whorton, 2014).

The evidence of $\mathrm{Ca}^{2+}$ activated chloride currents in human and rat cavernous smooth muscle cells was demonstrated by Karkanis and colleagues (Karkanis et al., 2003). In this study, the use of 4,4-dithitrostylbene-2,2-disulfonic acid (DNDS) and 4acetamido-4-isothiocyanostylbene-2,2-disulfonic acid, CaCC blockers, transiently increased intracavernous pressure and prolonged time of erection after cavernous nerve stimulation (Karkanis et al., 2003).
$\mathrm{CaCC}$ is associated with the maintenance of basal tone and spontaneous contractions of the corpus cavernosum. The use of two potential erectogenic agents, niflumic acid (NFA) and anthracene-9-carboxylic acid (A9C), CaCC channel blockers, significantly reversed intrinsic contractile activity of the rabbit's corpus cavernosum, as well as the tone of this tissue, after contraction with phenylephrine, histamine or endothelin-1, in a concentration-dependent manner (Linton et al., 2012).

In addition, when using isolated corpus cavernosum from diabetic rabbits, Chu and Adaikan (Leblanc et al., 2015) showed that NFA and A9C were able to increase the nitrergic relaxation of corpus cavernosum smooth muscle of diseased animals, suggesting that inhibition of $\mathrm{CaCC}$ may be a viable alternative to diabetes-related erectile dysfunction (Leblanc et al., 2015).

In recent study, by Hannigan and colleagues (Hannigan et al., 2017), the use of two new blockers $\left(\mathrm{T}_{16 \mathrm{~A}_{\mathrm{inh}}} \mathrm{A} 01\right.$ and $\mathrm{CaCC}_{\mathrm{inh}^{-}}$ A01) was effective in inhibiting $\mathrm{CaCC}$ channels, reducing the phenylephrine-induced tone, reinforcing their important role in favor of maintaining penile flaccidity (Hannigan et al., 2017).

\section{FUTURE PERSPECTIVES}

Despite recent advances and researching toward new therapeutic strategies for the treatment of erectile dysfunction, much remains has to be done to clarify the promising role of ion channels in controlling and determining male erectile function, as well as their participation in various other targets of the central and

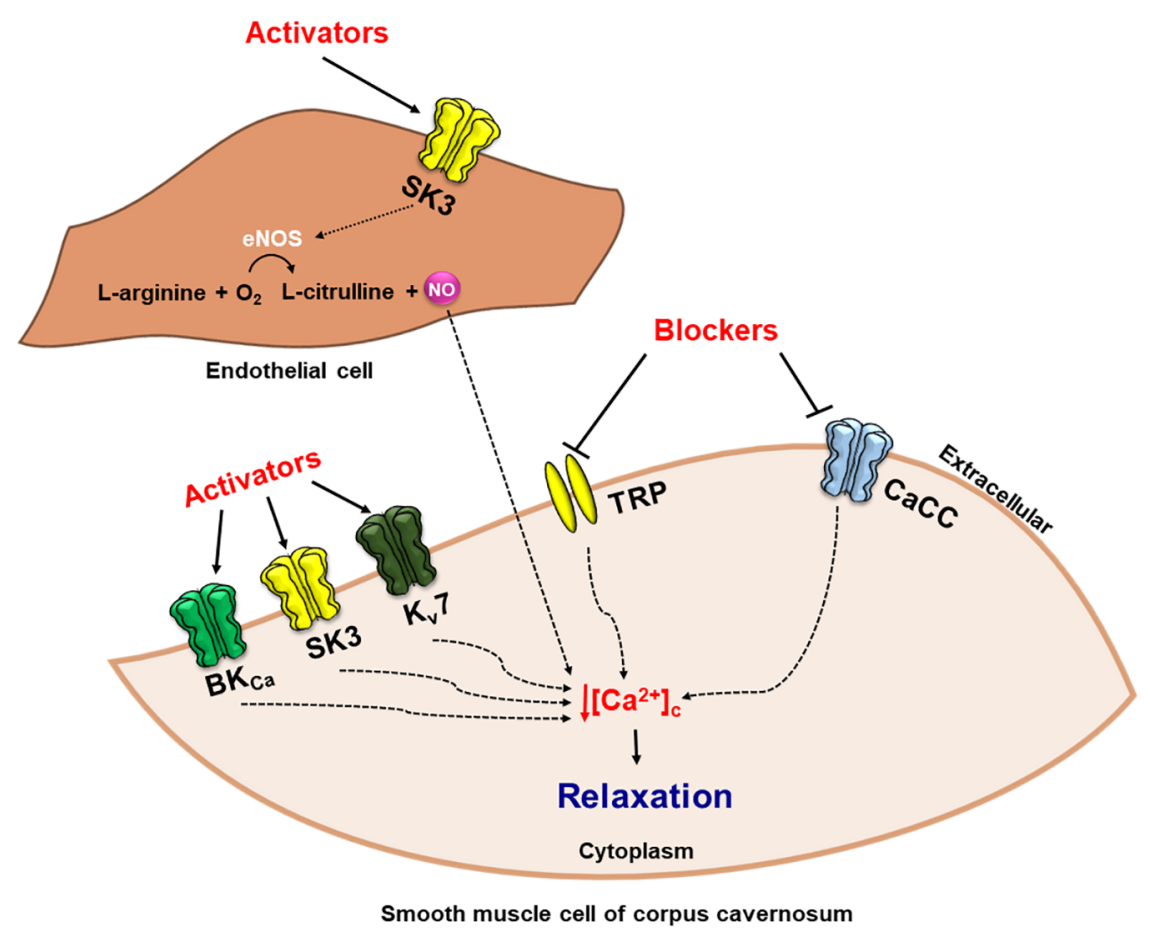

FIGURE 7 | Use of $\mathrm{BK}_{\mathrm{Ca}}$, SK3, and $\mathrm{K}_{\mathrm{V}} 7$ channels activators and/or transient receptor potential (TRP) and Calcium-activated Chloride channels (CaCC) blockers, induce reduction of cytoplasmic concentration of $\mathrm{Ca}^{2+},\left[\mathrm{Ca}^{2+}\right]_{\mathrm{c}}$, culminating in relaxation of the cavernous smooth muscle cell and penile erection. 
peripheral pathways involved in the regulation of cavernous smooth muscle tone. In this context, searching for new therapeutic targets that favor the penile erection process and the control of other aspects related to sexual function, the use of $\mathrm{BK}_{\mathrm{Ca}}, \mathrm{SK} 3$, and $\mathrm{K}_{\mathrm{v}} 7$ channels activators and/or TRPs and CaCC channels inhibitors represent important targets in the development of of possible pro-erectile agents leading to a decrease in cytosolic calcium concentration and consequently relaxation of the cavernous muscle cells, restoring erectile function and favoring penile erection (Figure 7). In addition, it is essential that the projections of these new therapeutic agents aim to reduce the side effects promoted by phosphodiesterase inhibitors, which is the most commonly, used first-line therapy for the treatment of ED. However, it is important to recognize that molecular and clinical understanding of sexual function, as well as patient and partner involvement, are critical to the implementation of successful therapy.

Based on the information presented, the modulation of ion channels seems to be a promising alternative for the treatment of

\section{REFERENCES}

Abbott, G. W. (2014). Biology of the KCNQ1 potassium channel. New J. Sci. 2014, 1-26. doi: 10.1155/2014/237431

Adelman, J. P., Maylie, J., and Sah, P. (2012). Small-conductance Ca2+-activated K + channels: form and function. Annu. Rev. Physiol. 74, 245-269. doi: 10.1146/ annurev-physiol-020911-153336

Alves, M. A. S. G., de Queiroz, T. M., and de Medeiros, I. A. (2012). Fisiologia peniana e disfunção erétil: uma revisão de literatura. ReBras CiêSaúde 6 , 439-444. doi: 10.4034/RBCS.2012.16.03.23

Andersson, K. E. (2001). Pharmacology of penile erection. Pharmacol. Rev. 53 (03), $417-450$.

Andersson, K. E. (2011). Mechanisms of penile erection and basis for pharmacological treatment of erectile dysfunctio. Pharmacol. Rev. 63, 811859. doi: 10.1124/pr.111.004515

Angulo, J., Cuevas, P., La Fuente, J. M., Pomeral, J. M., Ruiz-Castañé, E., Puigvert, A., et al. (2002). Regulation of human penile smooth muscle tone by prostanoid receptors. Br. J. Pharmacol. 136, 23-30. doi: 10.1038/sj.bjp.0704675

Antuña, V. C., Gómez, F. J. M., Escaf, S., and Fernández-González, F. (2015). Etiología neurógena en pacientes con disfunción erectil. Arch. Esp Urol. 61 (3), 403-411. doi: 10.4321/S0004-06142008000300007

Avery, L. L., and Scheinfeld, M. H. (2015). Imaging of penile and scrotal emergencies. Radiographics 33, 721-740. doi: 10.1148/rg.333125158

Awad, A., Alsaid, B., Bessede, T., Droupy, S., and Benoit, G. (2011). Evolution in the concept of erection anatomy. Surg. Radiol. Anat. 33 (4), 301-312. doi: 10.1007/s00276-010-0707-4

Ayta, I. A., McKinlay, J. B., and Krane, R. J. (1999). The likely worldwide increase in erectile dysfunction between 1995 and 2025 and some possible policy consequences. Br. J. Urol. Int. 84, 50-56. doi: 10.1046/j.1464-410x.1999. 00142.x

Balderas, E., Zhang, J., Stefani, E., and Toro, L. (2015). Mitochondrial BKCa channel. Front. Physiol. 6, 104. doi: 10.3389/fphys.2015.00104

Barman, S. A., Zhu, S., and White, R. E. (2004). Protein kinase C inhibits BKCa channel activity in pulmonary arterial smooth muscle. Am. J. Physiol. Lung Cell. Mol. Physiol. 286, L149-L155. doi: 10.1152/ajplung.00207.2003

Blair, N. T., Carvacho, I., Chaudhuri, D., Clapham, D. E., DeCaen, P., Delling, M., et al. (2019). Transient Receptor Potential channels (version 2019.4) in the IUPHAR/BPS Guide to Pharmacology Database. IUPHAR/BPS Guide Pharmacol. CITE. 2019, 4. doi: 10.2218/gtopdb/F78/2019.4

Boddi, V., Fanni, E., Castellini, G., Fisher, A. D., Corona, G., and Maggi, M. (2015). Conflicts within the family and within the couple as contextual factors in the erectile dysfunction. Despite this, it is necessary to emphasize the importance of investigating possible adverse effects that can happen after the modulation of ion channels. In this context, possible cardiovascular changes such as cardiac arrhythmias, hypotension or hypertension must have be ruled out to ensure the safe use of these possible new targets.

\section{AUTHOR CONTRIBUTIONS}

$\mathrm{AD}, \mathrm{RF}$, and IS made the major part of research, designed and wrote the manuscript. BS guided the preparation of the work.

\section{ACKNOWLEDGMENTS}

The authors thank CAPES and CNPq for financial support and UFPB for institutional support. determinism of male sexual dysfunction. J. Sexual Med. 12, 2425-2435. doi: $10.1111 /$ jsm. 13042

Brackett, L., Lynne, C. M., Ibrahim, E., Ohl, D. A., and SonkseN, J. (2010). Treatment of infertility in men with spinal cord injury. Nat. Rev. Urol. 7, 162172. doi: 10.1038/nrurol.2010.7

Brant, W. O., Bella, A. J., and Lue, T. F. (2007). Treatment options for erectile dysfunction. Endocrinol. Metab. Clin. North Am. 36, 465-479. doi: 10.1016/ j.ecl.2007.02.001

Brown, D. A., Passmore, G. M., and Neural, K. C. N. Q. (2009). (kv7) channels. Br. J. Pharmacol. 156, 1185-1195. doi: 10.1111/j.1476-5381.2009.00111.x

Brownstein, C. G., Dent, J. P., Parker, P., Hicks, K. M., Howatson, G., Goodall, S., et al. (2017). Etiology and recovery of neuromuscular fatigue following competitive soccer match-play. Front. Physiol. 8, 831. doi: 10.3389/fphys.2017.00831

Burnett, A. L., Nehra, A., Breau, R. H., Culkin, D. J., Faraday, M. M., Hakim, L. S., et al. (2018). Erectile dysfunction: AUA Guideline. J. Urol. 200, 633-641. doi: 10.1016/j.juro.2018.05.004

Cao, S., Anishkin, A., Zinkevich, N. S., Nishijima, Y., Korishettar, A., Wang, Z., et al. (2018). Transient receptor potential vanilloid 4 (TRPV4) activation by arachidonic acid requires protein kinase A-mediated phosphorylation. J. Biol. Chem. 293, 5307-5322. doi: 10.1074/jbc.M117.811075

Capogrosso, P., Ventimiglia, E., Boeri, L., Cazzaniga, W., Chierigo, F., Pederzoli, F., et al. (2019). Age at first presentation for erectile dysfunction: analysis of changes over a 12 -yr period. Eur. Urol. Focus 5, 899-905. doi: 10.1016/j.euf.2018.02.006

Caterina, M. J. (2014). TRP channel cannabinoid receptors in skin sensation, homeostasis, and inflammatio. ACS Chem. Neurosci. 5, 1107-1116. doi: $10.1021 / \mathrm{cn} 5000919$

Chadha, P. S., Zunke, F., Zhu, H.-L., Davis, A. J., Jepps, T. A., and Olesen, S. P. (2012). Reduced KCNQ4-Encoded Voltage-Dependent Potassium Channel Activity Underlies Impaired $\beta$-Adrenoceptor-Mediated Relaxation of Renal Arteries in Hypertension. Hypertension 59, 877-884. doi: 10.1161/ HYPERTENSIONAHA.111.187427

Chadha, P. S., Jepps, T. A., Carr, G., Stott, J. B., Zhu, H. L., Cole, W. C., et al. (2014). Contribution of Kv7. 4/Kv7. 5 heteromers to intrinsic and calcitonin gene-related peptide-induced cerebral reactivity. Arteriosclerosis Thrombosis Vasc. Biol. 34, 887-893. doi: 10.1161/ATVBAHA.114.303405

Chen, M. X., Gorman, S. A., Benson, B., Singh, K., Hieble, J. P., Michel, M. C., et al. (2004). Small and intermediate conductance $\mathrm{Ca} 2+$-activated $\mathrm{K}+$ channels confer distinctive patterns of distribution in human tissues and differential cellular localisation in the colon and corpus cavernosum. Naunyn-Schmiedeberg's Arch. Pharmacol. 369, 602-615. doi: 10.1007/s00210-004-0934-5 
Chu, L. L., and Adaikan, G. (2008). Role of chloride channels in the regulation of corpus cavernosum tone: a potential therapeutic target for erectile dysfunctio. J. Sexual Med. 5, 813-821. doi: 10.1111/j.1743-6109.2007.00728.x

Codevilla, C. F., Castilhos, T. S., and Bergold, A. M. A. (2013). review of analytical methods for the determination of four new phosphodiesterase type 5 inhibitors in biological samples and pharmaceutical preparations. Braz. J. Pharm. Sci. 29, 1-11. doi: 10.1590/S1984-82502013000100002

Comerma-Steffensen, S. G., Carvacho, I., Hedegaard, E. R., and Simonsen, U. (2017). Small and intermediate calcium-activated potassium channel openers improve rat endothelial and erectile function. Front. Pharmacol. 8, 660. doi: 10.3389/fphar.2017.00660

Comerma-Steffensen, S., Kun, A., Hedegaard, E. R., Mogensen, S., Aalkjaer, C., Köhler,R., et al. (2017). Down-regulation of K Ca 2.3 channels causes erectile dysfunction in mice. Sci. Rep. 7, 1-12. doi: 10.1038/s41598-01704188-5

Contreras, G. F., Castillo, K., Enrique, N., Carrasquel-Ursulaez, W., Castillo, J. P., Milesi, V., et al. (2013). A BK (Slo1) channel journey from molecule to physiology. Channels 7.6, 442-458. doi: 10.4161/chan.26242

Cordero, A., Bertomeu-Martínez, V., Mazón, P., Fácila, L., and González-Juanatey, J. R. (2010). Erectile dysfunction may improve by blood pressure control in patients with high-risk hypertension. Postgrad. Med. 122 (6), 51-56. doi: 10.3810/ pgm.2010.11.2223

Corona, G., Petrone, L., and Mannucci, E. (2006). Assessment of the relationship factor in male patients consulting for sexual dysfunction: the concept of couple sexual dysfunction. J. Androl. 27, 795. doi: 10.2164/ jandrol.106.000638

Cui, M., Qin, G., Yu, K., Bowers, M. S., and Zhang, M. (2014). Targeting the smalland intermediate-conductance $\mathrm{Ca} 2+$-activated potassium channels: The drugbinding pocket at the channel/calmodulin interface. Neurosignals 22, 65-78. doi: $10.1159 / 000367896$

Del Rocío Cantero, M., Velázquez, I. F., Streets, A. J., Ong, A. C., and Cantiello, H. F. (2015). The cAMP signaling pathway and direct protein kinase A phosphorylation regulate polycystin-2 (TRPP2) channel functio. J. Biol. Chem. 290, 23888-23896. doi: 10.1074/jbc.M115.661082

Doyle, C. (2011). "Characterisation of interstitial cells of cajal and smooth muscle cells in the corpus cavernosum," in PhD thesis (Dundalk, Co Louth: Dundalk Institute of Technology).

Eardley, I., Donatucci, C., Corbin, J., El-Meliegy, A., Hatzimouratidis, K., McVary, K., et al. (2010). Pharmacotherapy for erectile dysfunction. J. Sex Med. 7, 524540. doi: 10.1111/j.1743-6109.2009.01627.x

Eardley, I., Donatucci, C., Corbin, J., El-Meliegy, A., Hatzimouratidis, K., Mcvary, K., et al. (2013). Pharmacotherapy for erectile dysfunction. J. Sexual Med. 7, 524-540. doi: 10.1111/j.1743-6109.2009.01627.x

El Taieb, M. A., Hegazy, E. M., Maklad, S. M., and Khairy, R. (2019). Platelet Indices as a marker for early prediction of erectile dysfunction in diabetic patients. Andrologia 51, e13163. doi: 10.1111/and.13163

El-Sacca, A. (2007). Association of risk factors and medical comorbidities with male sexual dysfunction. J. Sexual Med. 4, 1691-1700. doi: 10.1111/j.17436109.2006.00342.x

Faber, E. S. L. (2009). Functions and modulation of neuronal SK channels. Cell Biochem. Biophysics 55, 127. doi: 10.1007/s12013-009-9062-7

Falzone, M. E., Malvezzi, M., Lee, B. C., and Accardi, A. (2018). Known structures and unknown mechanisms of TMEM16 scramblases and channels. J. Gen. Physiol. 150.7, 933-947. doi: 10.1085/jgp.201711957

Fauci, A. S., Hauser, S. L., Jameson, J. L., Kasper, D. L., Longo, D. L., and Loscalzo, J. (Eds.). (2012) Harrison's Principles of Internal Medicine. McGraw-Hill Education LLC. 18th ed, vol. 1, 374-378

Félétou, M. (2009). Calcium-activated potassium channels and endothelial dysfunction: therapeutic options? Br. J. Pharmacol. 156, 545-562. doi: 10.1111/j.1476-5381.2009.00052.x

Fumaz, C. R., Ayestaran, A., Perez-Alvarez, N., Muñoz Moreno J.Á, M. J., Ferrer, E., and Negredo, B. (2017). Clotet Clinical and emotional factors related to erectile dysfunction in HIV-infected men Am. J. Mens Health 11, 647-653. doi: 10.1177/ 1557988316669041

Gabrielson, A. T., Sartor, R. A., and Hellstrom, W. J. G. (2019). The impact of thyroid disease on sexual dysfunction in men and women. Sex Med. Rev. 7 (1), 57-70. doi: 10.1016/j.sxmr.2018.05.002
Gandaglia, G., Briganti, A., Montorsi, P., Mottrie, A., Salonia, A., and Montorsi, F. (2016). Diagnostic and therapeutic implications of erectile dysfunction in patients with cardiovascular disease. Eur. Urol. 70, 219-222. doi: 10.1016/ j.eururo.2016.01.054

Ghanem, H. M., Salonia, A., and Martin-Morales, A. (2012). Physical examination and laboratory testing for men with ED. J. Sexual Med. 10, 108-110. doi: 10.1111/j.1743-6109.2012.02734.x

Glina, S., Cohen, D. J., and Vieira, M. (2014). Diagnosis of erectile dysfunction. Curr. Opin. Psychiatry 27, 394-399. doi: 10.1097/YCO.0000000000000097

Goldstein, I. (2000). Oral phentolamine: an alpha-1, alpha-2 adrenergic antagonist for the treatment of erectile dysfunctio. Int. J. Impot. Res. 12 (Suppl 1), S75S80. doi: 10.1038/sj.ijir.3900502

Greenwood, I. A., and Ohya, S. (2009). New tricks for old dogs: KCNQ expression and role in smooth muscle. Br. J. Pharmacol. 156, 1196-1203. doi: 10.1111/ j.1476-5381.2009.00131.x

Grover, S. A., Lowensteyn, I., Kaouache, M., Lowensteyn, I., Kaouache, M., Marchand, S., Coupal, L., et al. (2006). The prevalence of erectile dysfunction in the primary care setting: importance of risk factors for diabetes and vascular disease. Arch. Intern Med. 166, 213. doi: 10.1001/ archinte.166.2.213

Gur, S., Kadowitz, J., Sikka, S. C., Bivalacqua, T. J., and Hellstrom, W. J. (2012). Inhibition of sympathetic neuroeffector transmission in human corpus cavernosum. BJU Int. 110, 856-862. doi: 10.1111/j.1464-410X.2011.10822.x

Gururaja Rao, S., Bednarczyk, P., Towheed, A., Shah, K., Karekar, P., Ponnalagu, D., et al. (2019). BKCa (Slo) channel regulates mitochondrial function and lifespan in Drosophila melanogaster. Cells 8, 945. doi: 10.3390/cells8090945

Haick, J. M., and Byron, K. L. (2016). Novel treatment strategies for smooth muscle disorders: Targeting Kv7 potassium channels. Pharmacol. Ther. 165, 14-25. doi: 10.1016/j.pharmthera.2016.05.002

Hannigan, K. (2016). "Regulation of corpus cavernosum activity by ion channel modulators," in PhD Thesis (Dundalk, Co Louth: Dundalk Institute of Technology).

Hannigan, K. I., Griffin, C. S., Large, R. J., Sergeant, G. P., Hollywood, M. A., and McHale, N. (2017). The role of $\mathrm{Ca}^{2+}$-activated $\mathrm{Cl}$ - current in tone generation in the rabbit corpus cavernosum. Am. J. Physiol. Cell Physiol. 313, C475-C486. doi: 10.1152/ajpcell.00025.2017

Hartzell, C., Putzier, I., and Arreola, J. (2005). Calcium-activated chloride channels. Annu. RePhysiol. 67, 719-758. doi: 10.1146/annurev.physiol.67.032003.154341

Hatzimouratidis, K., and Hatzichristou, D. G. (2005). A comparative review of the options for treatment of erectile dysfunctio. Drugs 65, 1621-1650. doi: 10.2165/ 00003495-200565120-00003

Hatzimouratidis, K., Amar, E., Eardley, I., Giuliano, F., Hatzichristou, D., and Montorsi, F. (2010). for the European Association of UrologyGuidelines on male sexual dysfunction: erectile dysfunction and premature ejaculatio. Eur. Urol. 57, 804-814. doi: 10.1016/j.eururo.2010.02.020

Hu, C. L., Wu, Y. D., Liu, H. T., Qin, W. B., and Wang, G. Z. (2009). Effect of thyroid hormone on the contents of NOS and CO in the penile corpus cavernosum of rats. Zhonghua nan ke xue=. Natl. J. Androl. 15 (1), 37-40.

Irwin, G. M. (2019). Erectile dysfunction. Prim. Care.: Clinics in Office Practice 46 (2), 249-255. doi: 10.1016/j.pop.2019.02.006

Jackson, G. (2007). The importance of risk factor reduction in erectile dysfunction. Curr. Urol. Rep. 8, 463-466. doi: 10.1007/s11934-007-0049-x

Jentsch, T. J. (2000). Neuronal KCNQ potassium channels: physislogy and role in disease. Nat. Rev. Neurosci. 1, 21-30. doi: 10.1038/35036198

Jepps, T. A., Olesen, S. P., Greenwood, I. A., and Dalsgaard, T. (2016). Molecular and functional characterization of Kv7 channels in penile arteries and corpus cavernosum of healthy and metabolic syndrome rats. Br. J. Pharmacol. 173, 1478-1490. doi: 10.1111/bph.13444

Jepps, T. A., Chadha, P. S., Davis, A. J., Harhun, M. I., Cockerill, G. W., Olesen, S. P., et al. (2011). Downregulation of Kv7. 4 channel activity in primary and secondary hypertensio. Circulation 124, 5, 602-611. doi: 10.1161/CIRCULATIONAHA. 111.032136

Jepps, T. A., Olesen, S. P., and Greenwood, I. A. (2013). One man's side effect is another man's therapeutic opportunity: targeting Kv7 channels in smooth muscle disorders. Br. J. Pharmacol. 168, 19-27. doi: 10.1111/j.14765381.2012.02133.x 
Joshi, S., Sedivy, V., Hodyc, D., Herget, J., and Gurney, A. M. (2009). KCNQ modulators reveal a key role for KCNQ potassium channels in regulating the tone of rat pulmonary artery smooth muscle. J. Pharmacol. Exp. Ther. 329, 368-376. doi: 10.1124/jpet.108.147785

Jung, J. H., Kim, B. J., Chae, M. R., Kam, S. C., Jeon, J. H., So, I., et al. (2010). Gene transfer of TRPC6DN (dominant negative) restores erectile function in diabetic rats. J. Sexual Med. 7.3, 1126-1138. doi: 10.1111/j.17436109.2009.01634.x

Kamaleddin, M. A. (2018). Molecular, biophysical, and pharmacological properties of calcium-activated chloride channels. J. Cell. Physiol. 233, 787798. doi: $10.1002 /$ jcp. 25823

Karkanis, T., DeYoung, L., Brock, G. B., and Sims, S. M. (2003). Ca2+-activated $\mathrm{Cl}$ - channels in corpus cavernosum smooth muscle: a novel mechanism for control of penile erectio. J. Appl. Physiol. 94.1, 301-313. doi: 10.1152/ japplphysiol.00660.2002

Katz, A. M. (2002). Ernest Henry Starling, his predecessors, and the "Lawof the Heart". Circulation 106 (23), 2986-2992. doi: 10.1161/01.CIR.0000040594.96123.55

Kaya, E., Sikka, S. C., and Gur, S. (2015). A comprehensive review of metabolic syndrome affecting erectile dysfunction. J. Sexual Med. 12, 856-875. doi: $10.1111 /$ jsm. 12828

Keen, J. E., Khawaled, R., Farrens, D. L., Neelands, T., Rivard, A., Bond, C. T., et al. (1999). Domains responsible for constitutive and Ca2+-dependent interactions between calmodulin and small conductance $\mathrm{Ca} 2+$-activated potassium channels. J. Neurosci. 19, 8830-8838, 20. doi: 10.1523/JNEUROSCI.19-2008830.1999

Keller, J. J., Liang, Y. C., and Lin, H. C. (2012). Association Between multiple sclerosis and erectile dysfunction: A nationwide case-control study. J. Sexual Med. 9, 1753-1759. doi: 10.1111/j.1743-6109.2012.02746.x

Khanamiri, S., Soltysinska, E., Jepps, T. A., Bentzen, B. H., Chadha, P. S., Schmitt, N., et al. (2013). Contribution of Kv7 channels to basal coronary flow and active response to ischemia. Hypertension 62, 1090-1097. doi: 10.1161/ HYPERTENSIONAHA.113.01244

Konstantinos, G., and Petros, P. (2009). Phosphodiesterase-5 inhibitors: future perspectives. Curr. Pharm. Des. 15 , 3540-3551. doi: 10.2174/ 138161209789206953

Kouba, S., Braire, J., Félix, R., Chantôme, A., Jaffres, P. A., Lebreton, J., et al. (2020). Lipidic synthetic alkaloids as SK3 channel modulators. Synthesis and biological evaluation of 2-substituted tetrahydropyridine derivatives with potential antimetastatic activity. Eur. J. Med. Chem. 186, 111854. doi: 10.1016/ j.ejmech.2019.111854

Kshatri, A. S., Li, Q., Yan, J., Large, R. J., Sergeant, G. P., McHale, N. G., et al. (2017). Differential efficacy of GoSlo-SR compounds on $\mathrm{BK} \alpha$ and $\mathrm{BK} \alpha \gamma(1-4)$ channels. Channels (Austin) 11, 66-78. doi: 10.1080/19336950.2016.1213930

Kun, A., Matchkov, V. V., Stankevicius, E., Nardi, A., Hughes, A. D., Kirkeby, H. J., et al. (2009). NS11021, a novel opener of large-conductance Ca2+-activated K+ channels, enhances erectile responses in rats. Br. J. Pharmacol. 158, 1465-1476. doi: $10.1111 / j .1476-5381.2009 .00404 . x$

Kupelian, V., Link, C. L., and Mckinlay, J. B. (2007). Association between smoking, passive smoking, and erectile dysfunction: results from the Boston Area Community Health (BACH) Survey. Eur. Urol. 52, 416-422. doi: 10.1016/ j.eururo.2007.03.015

Kushwah, N., Jain, V., Dheer, A., Kumar, R., Prasad, D., and Khan, N. (2018). Hypobaric Hypoxia-Induced Learning and Memory Impairment: Elucidating the Role of Small Conductance Ca2+-Activated K+ Channels. Neuroscience 388, 4184295. doi: 10.1016/j.neuroscience.2018.07.026

Leblanc, N., Forrest, A. S., Ayon, R. J., Wiwchar, M., Angermann, J. E., Pritchard, H. A., et al. (2015). Molecular and functional significance of $\mathrm{Ca}^{2+}$-activated $\mathrm{Cl}^{-}$ channels in pulmonary arterial smooth muscle. Pulmonary Circ. 5 (2), 244268. doi: $10.1086 / 680189$

Lee, S. W., Chae, M. R., Kang, S. J., Han, D. H., Sung, H. H., Chung, J. D., et al. (2018). 324 Characterization and functional roles of Kv7 Channels in corpus cavernosum smooth muscle. J. Sexual Med. 15, S255-S256. doi: 10.1016/ j.jsxm.2018.04.287

Lee, J. H., Chae, M. R, Kang, S. J., Sung, H. H., Han, D. H., So, I., et al. (2020). Characterization and functional roles of KCNQ-encoded voltage-gated potassium (Kv7) channels in human corpus cavernosum smooth muscle. Pflügers Archiv. European J. Physiol. 472 (1), 89-102. doi: 10.1007/s00424019-02343-7
Lewis, R. W., Fugl-Meyer, K. S., Corona, G., Hayes, R. D., Laumann, E. O., Moreira, E. D.Jr, et al. (2012). Definitions/epidemiology/risk factors for sexual dysfunction. J. Sex Med. 7, 1598-1607. doi: 10.1111/j.1743-6109.2010.01778.x

Linton, D. J., Lau, L. C., and Adaikan, G. (2012). Calcium-activated chloride channels in the corpus cavernosum: recent developments and future of a key cellular component of the erectile process. Int. J. Impotence Res. 24.6, 211. doi: 10.1038/ijir.2012.22

Lorca, R. A., Stamnes, S. J., Pillai, M. K., Hsiao, J. J., Wright, M. E., and d England, S. K. (2014a). N-terminal Isoforms of the Large-conductance $\mathrm{Ca}^{2+}$-activated $\mathrm{K}^{+}$ Channel Are Differentially Modulated by the Auxiliary beta1-Subunit. J. Biol. Chem. 289, 140095-140103. doi: 10.1074/jbc.M113.521526

Lorca, R. A., Prabagaran, M., and England, S. K. (2014b). Functional insights into modulation of BKCa channel activity to alter myometrial contractility. Front. Physiol. 5:289. doi: 10.3389/fphys.2014.00289

Ludwig, W., and Phillips, M. (2014). Organic causes of erectile dysfunction in men under 40. Urol. Internationalis 921, 1-6. doi: 10.1159/000354931

Lugg, J., Ng, C., Rajfer, J., and Gonzalez-Cadavid, (1996). Cavernosal nerve stimulation in the rat reverses castration-induced decrease in penile NOS activity. Am. J. Physiol. Endocrinol. Metab. 271, E354-E361. doi: 10.1152/ajpendo.1996.271.2.E354

Mackie, A. R., Brueggemann, L. I., Henderson, K. K., Shiels, A. J., Cribbs, L. L., Scrogin, K. E., et al. (2008). Vascular KCNQ potassium channels as novel targets for the control of mesenteric artery constriction by vasopressin, based on studies in single cells, pressurized arteries, and in vivo measurements of mesenteric vascular resistance. J. Pharmacol. Exp. Ther. 325, 475-483. doi: 10.1124/ jpet.107.135764

Maiorino, M.II, Bellastella, G., and Esposito, K. (2015). Lifestyle modifications and erectile dysfunction: what can be expected? Asian J. Androl. 17, 5. doi: 10.4103/ 1008-682X.137687

Maseroli, E., Corona, G., Rastrelli, G., Lotti, F., Cipriani, S., Forti, G., et al. (2015). Prevalence of endocrine and metabolic disorders in subjects with erectile dysfunction: a comparative study. J. Sexual Med. 12, 956-965. doi: 10.1111/ jsm. 12832

Mccabe, M. P., and Althof, S. E. (2014). A systematic review of the psychosocial outcomes associated with erectile dysfunction: Does the impact of erectile dysfunction extend beyond a man's inability to have sex? J. Sexual Med. 11, 347-363. doi: $10.1111 /$ jsm.12374

McCabe, M. P., Sharlip, I. D., Lewis, R., Atalla, E., Balon, R., Fisher, A. D., et al. (2016). Definitions of sexual dysfunctions in women and men: a consensus statement from the Fourth International Consultation on Sexual Medicine. J. Sex Med. 13, 135. doi: 10.1016/j.jsxm.2015.12.019

McManus, O. B., Helms, L. M., Pallanck, L., Ganetzky, B., Swanson, R., and Leonard, R. J. (1995). Functional role of the beta subunit of high conductance calcium-activated potassium channels. Neuron 14, 345-350. doi: 10.1016/0896-6273(95)90321-6

McVary, K. T., et al. (2012). "Sexual dysfunction," in Harrison"s: principles of internal medicine, 18th ed, vol. 1. Eds. D. L. Longo, A. S. Fauci and D. L. Kasper (New York: McGraw-Hill), 374-378.

Mills, T. M., Chitaley, K., Wingard, C. J., Lewis, R. W., and Webb, R. C. (2001). Effect of Rho-kinase inhibition on vasoconstriction in the penile circulatio. J. Appl. Physiol. 91, 1269-1273. doi: 10.1152/jappl.2001.91.3.1269

Mitidieri, E., Cirino, G., di Villa Bianca, R. D. E., and Sorrentino, R. (2020). Pharmacology and perspectives in erectile dysfunction in man. Pharmacol. Ther. 208, 107493. doi: 10.1016/j.pharmthera.2020.107493

Moran, M. M. (2018). TRP channels as potential drug targets. Annu. Rev. Pharmacol. Toxicol. 58, 309-330. doi: 10.1146/annurev-pharmtox-010617-052832

Moreland, R. B., Kim, N., Nehra, A., Goldstein, I., Traish, A., and Functional prostaglandin, E. (2003). (EP) receptors in human penile corpus cavernosum. Int. J. Impotence Res. 15, 362-368. doi: 10.1038/sj.ijir.3901042

Munk, N. E., Knudsen, J. S., Comerma-Steffensen, S., and Simonsen, U. (2019). Systematic Review of Oral Combination Therapy for Erectile Dysfunction When Phosphodiesterase Type 5 Inhibitor Monotherapy Fails. Sex Med. Rev. 7, 430-441. doi: 10.1016/j.sxmr.2018.11.007

Musicki, B., Liu, T., Lagoda, G. A., Strong, T. D., Sezen, S. F., Johnson, J. M., et al. (2010). Hypercholesterolemia-induced erectile dysfunction: endothelial nitric oxide synthase (eNOS) uncoupling in the mouse penis by $\mathrm{NAD}(\mathrm{P}) \mathrm{H}$ oxidase. $J$. Sex Med. 7, 3023-3032. doi: 10.1111/j.1743-6109.2010.01880.x

Nam, Y.-W., Orfali, R., Liu, T., Yu, K., Cui, M., Wulff, H., et al. (2017). Structural insights into the potency of SK channel positive modulators. Sci. Rep. 7, 1-10. doi: 10.1038/s41598-017-16607-8 
Nguyen, H. M. T., Gabrielson, A. T., and Hellstrom, W. J. G. (2017). Erectile dysfunction in young men-a review of the prevalence and risk factors. Sexual Med. Rev. 5, 508-520. doi: 10.1016/j.sxmr.2017.05.004

Nilius, B., and Owsianik, G. (2011). The transient receptor potential family of ion channels. Genome Biol. 12.3, 218. doi: 10.1186/gb-2011-12-3-218

Orimoloye, O. A., Feldman, D.II, and Blaha, M. J. (2019). Erectile dysfunction links to cardiovascular disease-defining the clinical value. Trends Cardiovasc. Med. 29, 458-465. doi: 10.1016/j.tcm.2019.01.002

Özdemirci, S., Yildiz, F., Utkan, T., Ulak, G., Çetinaslan, B., Erden, F., et al. (2001). Impaired neurogenic and endothelium-dependent relaxant responses of corpus cavernosum smooth muscle from hyperthyroid rabbits. Eur. J. Pharmacol. 428, 105-111. doi: 10.1016/S0014-2999(01)01268-7

Papagiannopoulos, D., Khare, N., and Nehra, A. (2015). Evaluation of young men with organic erectile dysfunction. Asian J. Androl. 17, 11. doi: 10.4103/1008682X.139253

Perimenis, P., Konstantinopoulos, A., Perimeni, P., Gyftopoulos, K., Kartsanis, G., Liatsikos, E., et al. (2006). Long-term treatment with intracavernosal injections in diabetic men with erectile dysfunctio. Asian J. Androl. 8, 219-224. doi: 10.1111/j.1745-7262.2006.00095.x

Perticone, F., Sciacqua, A., Maio, R., Perticone, M., Maas, R., Rh, B., et al. (2005) Asymmetric dimethylarginine, L-arginine, and endothelial dysfunction in essential hypertensio. J. Am. Coll. Cardiol. 46 (3), 518-523. doi: 10.1016/ j.jacc.2005.04.040,2005

Phe, V., and Roupret, M. (2012). Erectile dysfunction and diabetes: a review of the current evidence-based medicine and a synthesis of the main available therapies. Diabetes Metab. 38 (1), 1-13. doi: 10.1016/ j.diabet.2011.09.003

Picollo, A., Malvezzi, M., and Accardi, A. (2015). TMEM16 proteins: unknown structure and confusing functions. J. Mol. Biol. 2015427 (1), 94-105. doi: $10.1016 /$ j.jmb.2014.09.028

Porst, H. (1996). The rationale for prostaglandin E1 in erectile failure: a survey of worldwide experience. J. Urol. 155, 802-815. doi: 10.1016/S00225347(01)66315-8

Prieto, D. (2008). Physiological regulation of penile arteries and veins. Int. J. Impotence Res. 20, 17. doi: 10.1038/sj.ijir.3901581

Reggio, P. H., Muller, C., and Morales, P. (2018). Cannabinoid ligands targeting TRP channels. Front. Mol. Neurosci. 11, 487. doi: 10.3389/ fnmol.2018.00487

Riedner, C. E., Rhoden, E. L., Fuchs, S. C., Wainstein, M. V., Gonçalves, S. C., Wainstein, R. V., et al. (2011). Erectile dysfunction and coronary artery disease: an association of higher risk in younger men. J. Sexual Med. 8, 1445-1453. doi: 10.1111/j.1743-6109.2011.02224.x

Robbins, J. (2001). KCNQ potassium channels: physiology, pathophysiology, and pharmacology. Pharmacol. Ther. 90, 1-19. doi: 10.1016/S0163-7258 (01)00116-4

Rosen, E. D., and Spiegelman, B. M. (2014). What we talk about when we talk about fat. Cell 156, 20-44. doi: 10.1016/j.cell.2013.12.012

Rosen, R. C., Cappelleri, J. C., and Gendrano, 3. (2002). The International Index of Erectile Function (IIEF): a state-of-the-science review. Int. J. Impotence Res. 14, 226. doi: $10.1038 /$ sj.ijir.3900857

Sachs, B. D., and Meisel, R. L. (1988). The physiology of male sexual behavior. Physiol. Reprod. 2, 1393-1485. doi: 10.1159/000125049

Samanta, A., Taylor, E. T. H., and Moiseenkova-Bell, V. Y. (2018). "Transient Receptor Potential (TRP) Channels," in Membrane Protein Complexes: Structure and Function (Singapore: Springer), 141-165.

Schubert, R., and Nelso, M. T. (2001). Protein kinases: tuners of the BKCa channel in smooth muscle. Trends Pharmacol. Sci. 22.10, 505-512. doi: 10.1016/S01656147(00)01775-2

Seftel, A. D. (2011). Re: Erectile Dysfunction and Coronary Artery Disease: An Association of Higher Risk in Younger Men. J. Urol. 186, 1012-1018. doi: 10.1016/S0022-5347(11)60411-4

Selph, J. P., and Carson, C. C. (2011). Penile prosthesis infection: approaches to prevention and treatment. Urol. Clinics North America 38, 227-235. doi: 10.1016/j.ucl.2011.02.007

Shamloul, R., and Ghanem, H. (2013). Erectile dysfunctio. Lancet 381, 153-165. doi: 10.1016/S0140-6736(12)60520-0

Sheng, J.-Z., and Braun, A. (2007). Small-and intermediate-conductance Ca2 +-activated $\mathrm{K}+$ channels directly control agonist-evoked nitric oxide synthesis in human vascular endothelial cells. Am. J. Physiol. Cell Physiol. 293, C458C467. doi: 10.1152/ajpcell.00036.2007

Smani, T., Shapovalov, G., Skryma, R., Prevarskaya, N., and Rosado, J. A. (2015). Functional and physiopathological implications of TRP channels. Biochim. Biophys. Acta (BBA) Mol. Cell Res. 8 (2015), 1772-1782. doi: 10.1016/ j.bbamcr.2015.04.016

Soldovieri, M. V., Miceli, F., and Taglialatela, M. (2011). Driving with no brakes: molecular pathophysiology of Kv7 potassium channels. Physiology 26, 365376. doi: 10.1152/physiol.00009.2011

Sopko, A., Hannan, J. L., and Bivalacqua, T. J. (2014). Understanding and targeting the Rho kinase pathway in erectile dysfunctio. Nat. Rev. Urol. 11, 622-628. doi: 10.1038/nrurol.2014.278

Stott, J. B., Barrese, V., Jepps, T. A., Leighton, E. V., and Greenwood, I. A. (2015). Contribution of $\mathrm{Kv} 7$ channels to natriuretic peptide mediated vasodilation in normal and hypertensive rats. Hypertension 65, 676-682. doi: 10.1161/ HYPERTENSIONAHA.114.04373

Stott, J. B., Jepps, T. A., and Greenwood, I. A. (2014). KV7 potassium channels: a new therapeutic target in smooth muscle disorders. Drug Discovery Today 19, 413-424. doi: 10.1016/j.drudis.2013.12.003

Sung, H. H., et al. (2014). Increased expression of TRPC 4 channels associated with erectile dysfunction in diabetes. Andrology 2, 550-558. doi: 10.1111/j.20472927.2014.00214.x

Sung, H. H., Kang, S. J., Chae, M. R., Kim, H. K., Park, J. K., Kim, C. Y., et al. (2017). Effect of BKCa channel opener LDD175 on erectile function in an in vivo diabetic rat model. J. Sexual Med. 14 (1), 59-68. doi: 10.1016/ j.jsxm.2016.11.316

Swerdloff, R. S., and Wang, C. (2012). "The testis and male sexual function," in Goldman"s Cecil medicine, 24th ed, vol. 1. Eds. L. Goldman and A. I. Schafer (Philadelphia: Elsevier), 1519-1529.

Tabosa, A., Oliveira, D. C. D., Stangler, V. H., Araújo, H., Nunes, V., Gadelha, M. I., et al. (2017). Association between Erectile Dysfunction and Quality of Life in Patients with Coronary Artery Disease. Int. J. Cardiovasc. Sci. 30, 219-226. doi: 10.5935/2359-4802.20170042

Thomas, S., and Bohnen, A. M. (2005). Incidence rates of erectile dysfunction in the Dutch general populatioEffects of definition, clinical relevance and duration of follow-up in the Krimpen Study. Int. J. Impotence Res. 17, 58. doi: 10.1038/sj.ijir.3901264

Traish, A. M., Haider, A., Doros, G., and Saad, F. (2015). Long-term testosterone therapy in hypogonadal men ameliorates elements of the metabolic syndrome: An observational, long-term registry study. Int. J. Clin. Pract. 68, 314-329. doi: 10.1111/ijcp.12319

Wallner, M., Meera, P., Ottolia, M., Kaczorowski, G. J., Latorre, R., Garcia, M. L., et al. (1995). Characterization of and modulation by a beta-subunit of a human maxi $\mathrm{K}_{\mathrm{Ca}}$ channel cloned from myometrium. Recept. Channels 3, 385-399. Tanaka, 1997.

Werner, M. E., Zvara, P., Meredith, A. L., Aldrich, R. W., and Nelson, M. T. (2005). Erectile dysfunction in mice lacking the large-conductance calcium-activated potassium (BK) channel. J. Physiol. 567, 545-556. doi: 10.1113/ jphysiol.2005.093823

Whorton, M. (2014). Biologia estrutural: proteínas ativadas por cálcio visualizadas. Nature 516 (7530), 176. doi: 10.1038/nature13944

$\mathrm{Wu}, \mathrm{S}$. (2003). Large-conductance Ca2+-activated K+ channels: physiological role and pharmacology. Curr. Med. Chem. 10 (8), 649-661. doi: 10.2174/ 0929867033457863

Yafi, F. A., Jenkins, L., Albersen, M., Corona, G., Isidori, A. M., Goldfarb, S., et al. (2016). Erectile dysfunction. Nat. Rev. Dis. Primers 2, 1-47. doi: 10.1038/ nrdp. 2016.3

Yeung, S. Y. M., Pucovský, V., Moffatt, J. D., Saldanha, L., Schwake, M., Ohya, S., et al. (2007). Molecular expression and pharmacological identification of a role for Kv7 channels in murine vascular reactivity. Br. J. Pharmacol. 151, 758-770. doi: 10.1038/sj.bjp.0707284

Yeung, S. Y. M., Schwake, M., Pucovský, V., and Greenwood, I. A. (2008). Bimodal effects of the Kv7 channel activator retigabine on vascular $\mathrm{K}+$ currents. $\mathrm{Br}$. J. Pharmacol. 155, 62-72. doi: 10.1038/bjp.2008.231

Zelefsky, M. J., Shasha, D., Branco, R. D., Kollmeier, M., Baser, R. E., Pei, X., et al. (2014). Prophylactic sildenafil citrate improves select aspects of sexual function in men treated with radiotherapy for prostate cancer. J. Urol. 192, 868-874. doi: 10.1016/j.juro.2014.02.097 
Zhang, M., Pascal, J. M., Schumann, M., Armen, R. S., and Zhang, J. F. (2012). Identification of the functional binding pocket for compounds targeting smallconductance Ca 2+-activated potassium channels. Nat. Commun. 3, 1-10. doi: 10.1038/ncomms 2017

Zhong, X. Z., Harhun, M. I., Olesen, S. P., Ohya, S., Moffatt, J. D., Cole, W. C., et al. (2010). Participation of KCNQ (Kv7) potassium channels in myogenic control of cerebral arterial diameter. J. Physiol. 588, 3277-3293. doi: 10.1113/ jphysiol.2010.192823

Zhu, J.-H., Jia, R. P., Xu, L. W., Wu, J. P., Wang, Z. Z., Wang, S. K., and Bo, C. J. (2010). Reduced expression of SK3 and IK1 channel proteins in the cavernous tissue of diabetic rats. Asian J. Androl. 12, 599. doi: 10.1038/aja.2009.97
Conflict of Interest: The authors declare that the research was conducted in the absence of any commercial or financial relationships that could be construed as a potential conflict of interest.

Copyright (c) 2020 Diniz, Ferreira, de Souza and da Silva. This is an open-access article distributed under the terms of the Creative Commons Attribution License (CC BY). The use, distribution or reproduction in other forums is permitted, provided the original author(s) and the copyright owner(s) are credited and that the original publication in this journal is cited, in accordance with accepted academic practice. No use, distribution or reproduction is permitted which does not comply with these terms. 